\title{
SUPPLY NETWORK POSITION AND FIRM PERFORMANCE: EVIDENCE FROM CHINESE LISTED MANUFACTURING COMPANIES
}

\author{
Jinyan SHI, Jiangheng YANG, Yanxi LI \\ School of Economics and Management, Dalian University of Technology, Dalian, China
}

Received 16 May 2018; accepted 19 June 2019

\begin{abstract}
The aim of this paper is to examine the relationship between supply network position and firm performance. A-share manufacturing companies listed from 2013 to 2015 are chosen as the initial samples, and large sample supply networks are constructed with relational embeddedness and structural embeddedness. The location of supply network is depicted by network centrality and structural hole with social network analysis, and the influence of supply network position on the corporate performance is examined with multiple OLS regression analysis. This paper observes that a firms' supply network position is an important factor affecting its performance. The higher the network centrality is, the richer the structural holes are, and the worse the company's performance is. The results suggest that firms that have a high level of centrality or rich structural holes in their supply networks will gain limited information, resource and control benefits and face great business risks that may negatively influence their performance.
\end{abstract}

Keywords: firm performance, supply network position, network centrality, structural holes, relational embeddedness, structural embeddedness.

JEL Classification: G30, D21, Z13.

\section{Introduction}

As markets become increasingly competitive, numerous companies have adopted the practice of supply chain management (SCM) (Anderson \& Jap, 2005; Choi \& Krause, 2006). Thus, based on frequent business transactions, firms have strengthened ties with their major suppliers and customers. To assess whether these closer relationships actually help improve firms' performance, several researchers have chosen supplier concentration and customer concentration as the metrics to measure supply chain relationships and have studied their influence on firms' operating conditions and financial decisions (Irvine, Park, \& Ylldizhan, 2015; Patatoukas, 2011; Dhaliwal et al., 2016). However, although these metrics reflect the relational embeddedness between a firm and its direct suppliers and customers, they ignore

${ }^{\star}$ Corresponding author. E-mail: shijinyan@dlut.edu.cn; mrliyx@dlut.edu.cn 
structural embeddedness, which reflects relationships that go beyond immediate ties, such as the relationship between a firm and its customers' suppliers and customers or its suppliers' suppliers and customers ${ }^{1}$. Thus, considering the inadequacy of these metrics, this paper attempts to describe the supply chain relationship from a network perspective to account for its complexity and effect on firm performance.

In fact, a firm's embedded social networks have a substantial influence on its operating conditions and financial decisions. Relevant studies indicate that having a favorable position in a social network provides a firm with opportunities to improve innovation ability (Bell, 2005; Whittington, Owensmith, \& Powell, 2009; De Prato \& Nepelski, 2014), achieve higher return on investment (Hochberg, Ljungqvist, \& Lu, 2007; Larcker, So, \& Wang, 2013; El-Khatib, Fogel, \& Jandik, 2015), and secure financing at a lower cost (Chuluun, Prevost, \& Puthenpurackal, 2014; Engelberg, Gao, \& Parsons, 2012), which all help the firm to enhance overall performance (Zaheer \& Bell, 2005; Kim, 2017; Nee, Liu, \& DellaPosta, 2017; Carnovale, Rogers, \& Yeniyurt, 2019). As a vital social network where firms are embedded, the supply network exerts a pivotal influence on corporate economic behavior and outcomes. For example, in November 2016, the use of a low-cost pricing strategy left the LeTV phone supply chain in arrears, in turn triggering a capital chain crisis at LeTV Group. Subsequently, Huawei, the largest mobile phone manufacturing company in China, immediately sent numerous letters to its suppliers asking whether they also supplied to LeTV and were affected by the arrears. Specifically, given the fine division of labor in the mobile phone industry, suppliers that produce a single component for a phone may supply to various firms at the same time. If a supplier encounters cash flow difficulty or goes bankrupt because one of its clients goes into arrears, then the production and operating status of its other customers can also be affected. Actually, companies are not isolated players, instead, they are embedded in complex supply networks where the behavior of each company can influence the others. Therefore, it is necessary to examine the important impact of a firm's supply network when assessing firm performance.

In this paper, A-share manufacturing firms listed on the Shanghai and Shenzhen stock markets from 2013 to 2015 are adopted as initial samples and we examine their top five suppliers and customers to construct supply networks that capture the relational embeddedness of a firm relative to its direct suppliers and customers as well as the structural embeddedness of a firm relative to its indirect suppliers and customers. This paper focuses on manufacturing industry because it is the main body of Chinese national economy and companies that deal with upstream and downstream relationships are mainly positioned in it.

Using social network analysis (SNA), this paper computes indicators of a firm's centrality and structural holes abundance to measure the firm's network position characteristics. Then multiple linear OLS regression is conducted to explore the impact of supply network position on firm performance. The results indicate that both network centrality and structural holes have a negative effect on corporate performance, suggesting that in the supply network of the Chinese manufacturing industry, the firms embedded in the center or contain abundant structural holes always have poor performance due to the presence of risks and opportunism.

\footnotetext{
${ }^{1}$ Gulati (1998) defines relational embeddedness as the cohesion of direct ties and defines structural embeddedness as the indirect ties in a firm's network structure.
} 
Additionally, the paper examines the endogeneity of supply network position characteristics with Durbin-Wu-Hausman post-estimation test, which indicates structural holes abundance is endogenous. Then a two-stage least squares (2SLS) estimation procedure is adopted to settle the existing endogeneity problem. The results support the previous conclusion.

This paper contributes to the literature in two main respects. First, this paper enriches the dataset used to construct supply network. Specifically, empirical research on supply networks is relatively limited - a few researchers have established supply networks based on industrylevel data (Ahern \& Harford, 2014) or firm-level data that only includes a single industry such as the automobile industry (Kim et al., 2011; Dong et al., 2015) or the electronics industry (Bellamy, Ghosh, \& Hora, 2014). Sharma et al. (2019) used manual collecting data to establishe supply networks of international business. Some researchers have established relational embeddedness supply networks by using the data of firms' major customers in multiple industries (Kao et al., 2017; Kim, 2017). In contrast to these studies, this paper uses the data of firms' major customers and suppliers, and the data of that firm' customers' suppliers and customers or that firm' suppliers' suppliers and customers (In this way, there are many firms in other industries besides manufacturing firms are including in this network) to construct a more complete supply network with both relational and structural embeddedness. Second, this paper enriches the research on the factors influencing corporate performance. Specifically, scholars have regarded firms as isolated individuals and provided empirical evidence of various factors that influence firm performance, including micro-level factors such as board characteristics (Withers \& Fitza, 2017) and corporate governance (Akdogan \& Boyacioglu, 2014; Detthamrong, Chancharat, \& Vithessonthi, 2017) as well as macro-level factors such as economic environment (Park, Li, \& David, 2006) and cultural systems (Faruq \& Weidner, 2018). However, this paper adopts a meso-level perspective to study the effect of supply networks on firm performance, which not only complements the literature on corporate performance but also expands the application of social network theory in corporate finance.

The remainder of the paper is organized as follows. Section 1 presents the literature review and the development of hypotheses; Section 2 describes the construction of supply networks, the data sources, and the variables for empirical study. The empirical results and the robustness test are provided in Section 3. Finally, we conclude and discuss the implications.

\section{Literature review and hypothesis development}

\subsection{Literature review}

Social networks provide firms with a bridge to interact and exchange, so they play a critical role in firms' economic behavior and outcomes (Granovetter, 1985; Burt, 1992; Gulati, 1998). More and more studies of corporate finance have been undertaken from a social network perspective. Numerous authors have assembled various types of social networks, such as board network (Larcker, So, \& Wang, 2013), CEO network (El-Khatib, Fogel, \& Jandik, 2015), venture capital network (Hochberg, Ljungqvist, \& Lu, 2007) and so on, and they have provided empirical evidence of these networks' effects on corporate governance (Chen, Wang, \& Lin, 2014; Nee, Liu, \& DellaPosta, 2017; Kim, 2017). 
Supply networks share common features with these networks in terms of information acquisition and reciprocal cooperation. However, differences also exist between them. In particular, there are frequent business transactions between connected firms in a supply network. Choi and Hong (2002) first argued that buyers and suppliers should be seen as actors in complex adaptive networks. Subsequently, numerous theoretical studies about supply networks have been proposed. Specifically, scholars have analyzed the intrinsic value of network structure to the firm (Autry \& Griffis, 2008), proposed SNA measures to quantify that value (Borgatti, Mehram, \& Labianca, 2009), studied the dynamics of complete networks, and demonstrated the utility of SNA in understanding corporate risk (Basole \& Bellamy, 2014; Kim, Chen, \& Linderman, 2015)

By contrast, due to the difficulty in obtaining network data, only a few empirical studies have been conducted into supply networks. Among them, some scholars focused on specific industry to construct supply networks (Choi \& Hong, 2002; Kim et al., 2011; Bellamy, Ghosh, \& Hora, 2014; Dong et al., 2015). Choi and Hong (2002) used case studies to map the supply networks of the American automotive industry. Bellamy, Ghosh, and Hora (2014) focused on the electronics industry. They selected 151 of the world's top electronics businesses as samples from the Electronics Business 300 (EB 300) and used data from 2007-2008 to obtain the relationships between suppliers and customers and assembled the supply network. They studied the impact of supply network structure on corporate innovation. However, small sample size may result in an artificial narrowing of the network where the companies are embedded, so some scholars began to use data from multiple industries to construct supply networks (Kim, 2017; Kao et al., 2017). By drawing on the information of 717 suppliers and their major customers from the Compustat database, Kim (2017) identified the major customer networks and reported that customer interconnection has a positive influence on a supplier's profitability. Similarly, by using the major customer disclosures data, some scholars constructed supply chain (Kao et al., 2017; Kao, Su, \& Chen, 2019), and studied the impacts of supply network structure on corporate productive efficiency. In addition, based on the input-output (IO) accounts provided by the Bureau of Economic Analysis, Ahern and Harford (2014) also constructed supply networks at the industry level, revealing the importance of these industrial networks in explaining the formation and propagation of merger waves.

In summary, with the application of social network theory in corporate finance, studies on supply networks have aroused widespread interest among scholars. However, among the empirical literatures on supply networks, there are still certain limitations on the portrayal of supply network, and scholars pay little attention to the impact of supply network on firm performance.

\subsection{Research hypotheses}

In general, two methods are used to describe the characteristics of social networks: one is to measure the characteristics of the entire network, such as size and density; the other is to measure the position characteristics of individuals in the network, such as centrality and structural holes. Specifically, the characteristics of the entire network have the same effect on each node. However, the positional characteristics of each node can reflect its unique 
positional advantages in the network. Therefore, to distinguish the influence of a supply network on different firms' performance, indicators of position characteristics are adopted to describe the structure of the supply network, after which the paper analyzes their effects on firm performance.

\subsubsection{Network centrality and firm performance}

Actors in social economic activities usually perform autonomously, but they are simultaneously embedded in an interactive network that influences their actions (Burt, 1992; Granovetter, 1985; Gulati, 1998; Uzzi, 1997). Network centrality is a typical indicator of a firms' structural position in a network and is often used to evaluate the importance of the actors and measure their superiority, privilege, and social prestige (Marsden, 2002; Kim et al., 2011).

In general, holding the central position in a supply network may affect firm performance in the following ways. First, a firm with a more central position in a supply network has a higher number of direct and indirect connections with other firms, which can promote the integration of complementary resources and beneficial cooperation among firms, thus improving firm profitability (Rothaermel, 2001; Baum, Calabrese, \& Silverman, 2015; Bagul \& Mukherjee, 2018). Second, compared with firms with a marginal position in a supply network, centrally located firms have greater access to accurate and valuable information (Burt, 1992), which is crucial in helping firms develop effective strategies, reduce the operating costs of diversified business (Hoskisson, Hitt, \& Hill, 1993), and gain higher returns on investments (Larcker, So, \& Wang, 2013). Third, firms with a central position in the supply network can gain a degree of control advantages. Specifically, the benefits acquired from supply network affiliations provide firms located in the center with the first-mover advantage, yielding competitive and strategic superiority and providing them with the opportunity to define the supply network specifications. Thus, given these benefits, the paper develops the following hypothesis:

H1a: In the supply network of manufacturing industry, network centrality has positive impact on firm performance.

Supply network risks cannot be ignored when considering the effect of network centrality on firm performance. Specifically, supply network is a complex system consisting of both relational embeddedness and structural embeddedness, and the connected firms embedded in it have frequent business transactions and fund connections. In this context, poor decisions by some firms in the supply network can lead to inefficiency and even the collapse of the whole network (Weisbuch \& Battiston, 2007). This risk is even more pronounced in the supply network consisted of major suppliers and customers, for the following reasons. First, to optimize economic order quantity and reduce procurement costs, manufacturing companies often choose to organize deals with a few specific suppliers. Hence, the production and operation of these firms can be strongly affected by the price and quality of the suppliers' products (Porter, 1980). Companies thereby become more dependent on their major suppliers. Second, most manufacturing companies do not have independent marketing channels to reach consumers directly, so they rely on distributors (especially their major customers) to help them sell products and gain profits (Lanier, Wempe, \& Zacharia, 2010). Hence, if a company's major customers default or go bankrupt, the company could face substantial 
losses. In short, the firm located at the center, which has numerous relationships with other firms, is more vulnerable to other firms' unfavorable conditions, such as decision-making mistakes, poor management, and financial deterioration, which may negatively affect the performance of the central firm (Rezapour et al., 2018). From this perspective, this paper introduces the following hypothesis:

H1b: In the supply network of manufacturing industry, network centrality has negative impact on firm performance.

\subsubsection{Structural holes and firm performance}

Structural hole is another indicator commonly used to characterize the positions of nodes in a social network. Burt (1992) defined a structural hole as "a relationship of non-redundancy between two contacts".

In general, a firm can benefit from being rich in structural holes in the following ways. First, the information advantage provided by structural holes can promote the firm's performance. Specifically, according to Granovetter's theory, individuals with numerous strong ties tend to be limited to small groups where the information disseminated is often redundant (Granovetter, 1985). Conversely, individuals with a greater number of weak ties can obtain novel information from a wider range and gain information benefits. Companies with numerous structural holes have a lot of weak ties, so they can acquire valuable information and gain earlier insight into the opportunities and risks in the supply network, which is of great importance to improving corporate performance. More specifically, accurate and timely information helps companies make beneficial decisions, seize profit opportunities, and improve venture performance (Vissa \& Chacar, 2009), and non-redundant information can boost a firm's innovation ability and competitive strength (Yang et al., 2010; Bellamy, Ghosh, \& Hora, 2014).

The second manner in which structural holes can benefit firm performance is through the control advantages they yield. Specifically, firms with rich structural holes in a supply network can easily get and control the information, technology, and knowledge. Thus, they can influence the interests of other parties after guaranteeing own interests and boost own reputation in the network (Burt, 1992). Moreover, firms occupying rich structural holes can use their control advantage to prevent other firms from filling structural holes and thus continue receiving these benefits. Hence, this paper develops the following hypothesis:

H2a: In the supply network of manufacturing industry, structural holes have positive impact on firm performance.

The effect of structural holes on corporate performance is not always positive, because the market and cultural environment also influence it. From the perspective of the market environment, with the spread of economic globalization, firms strengthen cooperation with upstream and downstream firms. However, most companies have limited capacity to safeguard their own interests to restrain the opportunism of powerful partners. In the context, a firm with fewer structural holes can be considered embedded in a "closed" network, in which firms are provided with an external governance mechanism that can promote trust and cooperation between members by offering social rewards and punishments (Coleman, 1988; Kim, 2017). By contrast, it's hard for firms with rich structural holes to get the collec- 
tive governance. Therefore, in an increasingly complex market environment, companies occupying rich structural holes are more susceptible to their partners' opportunistic behaviors, which runs counter to their interests.

Furthermore, from the perspective of cultural environment, Xiao and Tsui (2007) proposed that companies in China were not encouraged to gain control or information benefits from structural holes due to the spirit of cooperation, which is the dominant spirit of Chinese collectivist culture. Specifically, a firm with rich structural holes, which exhibits a departure from traditional culture, is less likely to be trusted by other firms. In a highly competitive market, it's important to establish partnerships and trust is the key to promoting cooperation between firms. Therefore, the occupation of abundant structural holes can limit the opportunities for a firm to communicate and cooperate with others, thus weakening the its profitability and competitiveness. On the basis of this, the following hypothesis is introduced:

$H 2 b$ : In the supply network of manufacturing industry, structural holes have negative impact on firm performance.

Figure 1 illustrates the research hypotheses by exhibiting the influence mechanisms of supply network position on firm performance.

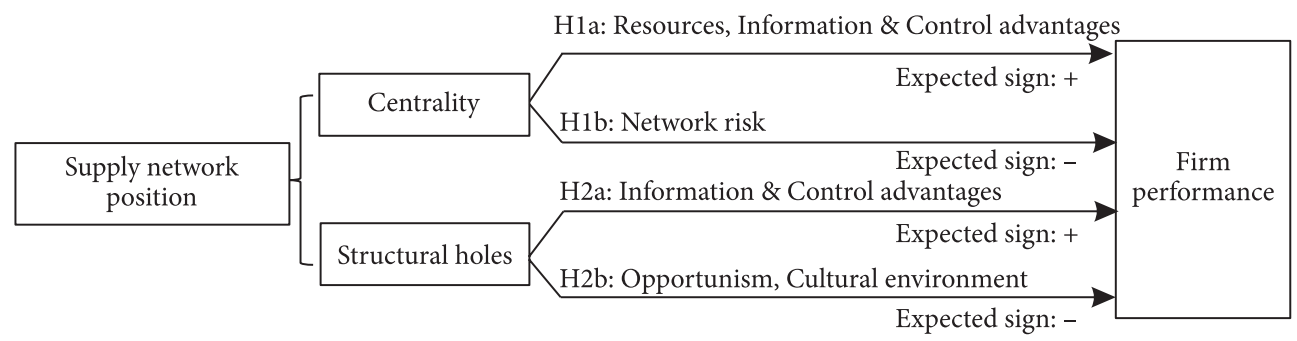

Figure 1. Research hypotheses: the influence of supply network position on firm performance

\section{Research methodology and data}

\subsection{Supply network construction approach and data collection}

A database is constructed from the following data sources: the China Stock Market \& Accounting Research (CSMAR) database and annual reports of some companies. This paper summarizes the data collection and supply network construction approach in the following five steps.

Step 1: The A-share manufacturing firms listed on the Shanghai and Shenzhen stock markets from 2013 to 2015 are identified as "lead companies". Then the top five suppliers and customers of these firms are identified from the CSMAR database.

Step 2: Judging whether the top five suppliers or customers are listed. This step is necessary because non-listed companies typically do not divulge the type of information relevant to this study, which could limit the research.

Step 3: Based on the information obtained in step 2, this paper selected those suppliers and customers that are listed firms and then examine their annual reports to identify their 
top five suppliers and top five customers. Then steps 2 and 3 are repeated until as much information have been collected as we can. Regarding this data collection process, the following points is noteworthy: (1) For some companies based outside of China, information about their major suppliers and customers are not collected. The reason is that there are several differences among companies in different countries, which may increase the difficulty of data acquisition and comparison. (2) For some major suppliers or customers that are branches of certain big companies, this paper replaces them with their parent companies. The reason is that branches have no independent legal personality but their interests are closely linked with the parent company.

Step 4: In order to identify the supply network relationships for these firms, this paper first establishes the relationship list "Firm Name-Name of Major Supplier (Customer)". Then, this paper replaces the company name with a stock code if the firm is listed. After that, this paper transforms the relationship lists into web forms with Creatpajek. Finally, the position indicators of each firm are calculated using Pajek.

Step 5: Among all the firms embedded in the supply network, the listed ones are selected as the subjects of this study (excluding companies in the financial industry and companies listed on the Hong Kong stock market) and we match them with financial data. Ultimately, the final sample of firms for the regression analysis step is 3,630.

Furthermore, to eliminate the influence of extrema, all continuous variables are winsorized at $1 \%$ and $99 \%$.

\subsection{Measurement of the variables}

\section{Dependent variables}

Return on assets (ROA) are used as the indicator of a firm's overall performance because it captures both the profitability and asset efficiency of the company.

\section{Independent variables}

This paper includes two main independent variables: network centrality and structural holes abundance.

(1) Network centrality. Until now, the indicators used to measure network centrality have mainly included degree centrality, betweenness centrality, eigenvector centrality, and closeness centrality. Specifically, degree centrality refers to the total number of direct links a firm has to other firms in the network. Betweenness centrality measures the role of a company as a "bridge." A company has a high level of betweenness centrality if it is positioned in the path of several corporate interactions. Eigenvector centrality measures how well connected a firm is to other well-connected firms in a network, which means that a firm with a high level of eigenvector centrality is more likely to be connected with firms that have central positions. Closeness centrality is the inverse of the sum of the shortest distance a firm is from every other firm in the network, which examines the independence of a company in acquiring information and resources. A firm with high closeness centrality may be more autonomous and depend less on others. However, closeness centrality is most often used to measure position characteristic of firms embedded in fully connected networks. Because the nodes in supply 
networks of this paper are not completely connected, this indicator is not been adopt. On the basis of this, the natural log of degree centrality (lnDegree) is used as the proxy of network centrality and the eigenvector centrality (Eigenvector) is used as a surrogate measure for a further robustness test. Additionally, because betweenness centrality reflects the "gate keeping" capability of a firm (Kim et al., 2011; Yan et al., 2015), its natural log (lnBetweenness) is used as a proxy of structural holes abundance in the robustness tests to examine the influence of structural holes on firm performance. All of these indicators are calculated using Pajek.

(2) Structural holes abundance. Burt (1992) proposed four indicators to measure the abundance of structural holes occupied by a firm: effective size, efficiency, constraint, and hierarchy. Among them, constraint index is widely used. Values of this measure range from 0 to 1 , and the higher it is, the fewer structural holes a firm occupies, so scholars usually define a new index as equal to 1 minus the constraint index to positively measure the abundance of structural holes (Zaheer \& Bell, 2005). Following the common practice in the literature, this paper first calculates the constraint index of each company by Pajek and then subtracts this number from 1 to derive a new index. After that, the natural log of the new index $(\operatorname{lnCI})$ is used as the proxy of structural holes abundance for further regression analysis.

\section{Control variables}

To control for extraneous effects of a firm's characteristics on corporate performance, this paper follows prior literatures and introduces the following control variables: (1) Firm size (Size). The size of a company not only determines the resources available to the company but also determines its operating costs, which has impact on firm performance. It is measured as the natural log of total sales. (2) Debt asset ratio (Lev). Corporate financial leverage is closely related to firm performance (Booth et al., 2001). This paper controls for it using the ratio of debt to total assets. (3) Nature of ownership (Owner). Compared with private enterprises, state-owned companies are usually considered to have poorer performance (Sun \& Tong, 2003). A dummy variable is used to control for it, where state-owned and non-state-owned enterprises are expressed as 1 and 0 , respectively.

Firm growth indicates the recent success of the firm and is anticipated to be related positively to corporate performance. The company's development potential is measured from the aspects of corporate sustainability, profitability and firm value, and introduce the following control variables:(4) Sustainable growth rate of the previous year (Sgr), measured as: $\frac{R O E \times \text { Retention ratio }}{1-R O E \times \text { Retention ratio }}$ and defined as the highest sales growth rate that the company can be expected to achieve this year under the operating efficiency and financial policies of the previous year. (5) Growth rate of net profit (Egr), measured as the growth rate of annual net profit. (6) Tobin's Q ratio (Q), measured as the ratio of market value to the replacement value of total assets. The use of these control variables helps mitigate the omitted variable bias.

Moreover, (7) Year (Year), expressed as binaries indicating 2013, 2014, and 2015. Year is controlled to reduce the potential correlation of performance measures within a specific year. 


\subsection{Model specification}

Multiple regression analyses are performed to determine the predicted relationship between the specified variables. Specifically, the following econometric models are constructed:

$$
\begin{aligned}
& R_{R A_{i, t}}=\alpha_{0}+\alpha_{1} \text { LnDegree }_{i, t}+\alpha_{2} \text { Size }_{i, t}+\alpha_{3} \text { Lev }_{i, t}+\alpha_{4} \text { Sgr }_{i, t}+ \\
& \alpha_{5} \text { Egr }_{i, t}+\alpha_{6} Q_{i, t}+\alpha_{7} \text { Owner }_{i, t}+\sum \text { Year }+\varepsilon_{i, t} \\
& R_{O A} \\
& \beta_{5} \text { Egr }_{i, t}+\beta_{0}+\beta_{6} Q_{i, t}+\beta_{7} \text { Owner }_{i, t}+\beta_{2} \text { Size }_{i, t}+\beta_{3} \text { Lev }_{i, t}+\beta_{4} \text { Sgr }_{i, t}+
\end{aligned}
$$

where $i$ represents the individual firm and $t$ represents the year. Model (1) examines the influence of supply network centrality on firm performance and Model (2) examines the impact of supply network structural holes on corporate performance. The two models have same control variables.

Considering that the interval of the samples is short (only including 3 years) and there are also some differences in the sample companies are selected for study each year, Ordinary Least Squares (OLS) regression with pool data is conducted to estimate the coefficients of Model (1) and Model (2).

However, according to the research of Bellamy, Ghosh, and Hora (2014) on the impact of supply network structure on firm innovation, the authors propose that there may be endogeneity problems in the characteristics of supply network structure. Correspondingly, as for this study, a firm's performance may become a valuable reference for other firms to establish contact with it; thus, its performance may affect its position characteristics in the supply network. Therefore, it's necessary to test the existence of such endogeneity. A popular and efficient way of testing the endogeneity of specific variables is to use the Durbin-Wu-Hausman post-estimation test. To adopt a Durbin-Wu-Hausman post-estimation test, adequate instrumental variables are needed to find to estimate the error terms of potentially endogenous variables, and then the predicted error terms are added to the original count model to test their significance. If the P-values of the significance test about the predicted error terms are greater than 0.1 , then it indicates that there is no endogeneity problem in the potentially endogenous variables. Hence, referencing to the study of Bellamy, Ghosh, and Hora (2014), closeness centrality (lnCloseness) is chosen as the instrument of $\ln$ Degree and $\operatorname{lnCI^{2}}$ and conduct a Durbin-Wu-Hausman post-estimation test. The paper examines the validity of the instrumental variable by judging whether it is related to the potential endogenous variables and whether the significance test statistic F-value of its regression coefficient is higher than the empirical reference value 10 .

\footnotetext{
$\overline{2}$ Bellamy, Ghosh, and Hora (2014) conducted a two-stage least squares regression analysis in their study of the influence of supply network structure on firm innovation, choosing degree centrality and number of pairs as instruments for assumed endogenous structural characteristics: network accessibility and network interconnectedness. Correspondingly, network accessibility and number of pairs are chosen as the instruments of network centrality and structure holes abundance. Network accessibility is similar to closeness centrality, so the indicator of closeness centrality is chosen as the instrument for the two indicators of network position characteristics. Moreover, because the number of nodes involved in the constructed supply network is very high, the number of pairs of each node cannot be calculated by using Ucinet or Pajek. Thus, number of pairs is not adopted as an instrument.
} 
After the Durbin-Wu-Hausman post-estimation test, the paper further adopts the twostage least squares (2SLS) estimation procedure to solve the existing endogeneity problem. Specifically, for supply network position variable that is endogenous, the paper regresses it on all assumed exogenous variables to calculate its predicted value in the first stage, and then conducts the second-stage regression by using the predicted value instead of its original value in the original count model and examine whether the regression results are consistent with the previous conclusion.

\section{Empirical analysis}

\subsection{Descriptive statistics}

(1) This paper constructs the supply networks consisting of relationships between firms with their direct and indirect major suppliers and customers from 2013 to 2015 . The features of these supply networks can be described as follows. First, in terms of the supply network size, 15,605 companies are involved in the 2013 supply network, of which 1,505 are listed companies; 11,650 firms are embedded in the 2014 supply network, of which 1,101 are listed companies; and the 2015 supply network consists of 15,699 firms, of which 1,465 are listed.

(2) The descriptive statistics of the variables used in regression analysis are presented in Table 1. It can be found that most of the listed companies have poor performance (the mean of ROA = 0.0406), with some even suffering losses. According to the descriptive statistics for network position measures, the mean of lnDegree is 2.2990, whereas the minimum and maximum are 1.0986 and 3.5363 respectively; $\operatorname{lnCI}$ has a mean of -0.1071 and a standard deviation of 0.0170 , it can be found that a wide range among firms concerning network centrality and structural holes abundance. These results demonstrate that the sample firms have distinctive characteristics of corporate performance and network position, which merits further study.

Moreover, to test the possible problem of collinearity between explanatory variables, a correlation analysis is firstly performed. The results show that all the correlation coefficients

Table 1. Summary statistics

\begin{tabular}{|l|c|c|c|c|c|}
\hline \multicolumn{1}{|c|}{ Variables } & $\mathrm{N}$ & Mean & Std. dev. & Min & Max \\
\hline ROA & 3630 & 0.0406 & 0.0582 & -0.1567 & 0.2178 \\
\hline lnDegree & 3630 & 2.2990 & 0.1177 & 1.0986 & 3.5263 \\
\hline lnBetweenness & 3630 & -3.3812 & 2.4824 & -16.3148 & -5.9563 \\
\hline lnCI & 3630 & -0.1071 & 0.0170 & -0.2231 & -0.0870 \\
\hline Eigenvector & 3630 & 0.0023 & 0.0146 & 0.0000 & 0.1146 \\
\hline Size & 3630 & 21.2470 & 1.3798 & 18.2799 & 25.3276 \\
\hline Lev & 3630 & 0.4062 & 0.2035 & 0.0479 & 0.9101 \\
Sgr & 3630 & 0.0381 & 0.1015 & -0.4779 & 0.3131 \\
\hline Egr & 3630 & 0.1780 & 0.3085 & -0.2739 & 1.7449 \\
\hline Q & 3630 & 2.6913 & 2.3343 & 0.2004 & 12.5023 \\
\hline Owner & 3630 & 0.2930 & 0.4552 & 0.0000 & 1.0000 \\
\hline
\end{tabular}


between explanatory variables are less than 0.5 , indicating the problem of collinearity is not particularly relevant in the regression models. In addition, the variance inflation factors (VIFs) are assessed to determine the significance of multicollinearity among independent variables. The results show that VIFs range from 1.03 to 1.86 in econometric model (1) and range from 1.02 to 1.84 in econometric model (2), which are well below the threshold value of 10 , suggesting that multicollinearity should not be a concern for further analysis.

\subsection{Main results and analysis}

The results of OLS regression with pool data are presented in Table 2. Model (1) tests the influence of $\ln$ Degree on ROA. The results reveal a negative association between $\ln$ Degree and ROA at a significance level of $1 \%(\beta=-0.0169, p<0.01)$, thus providing support for Hypothesis $1 b$. Therefore, this paper concludes that in the supply network consisting of major suppliers and customers, a firm with a higher level of centrality may be more vulnerable to adverse effects from mistakes or financial difficulties at other companies due to their close economic interaction and high degree of interest-relatedness; thus, such firms face higher operating risks.

Table 2. Network centrality, structural holes, and firm performance

\begin{tabular}{|c|c|c|}
\hline Variables & (1) ROA & (2) $\mathrm{ROA}$ \\
\hline \multirow{2}{*}{ lnDegree } & $-0.0169^{* * *}$ & \\
\hline & $(-2.9566)$ & \\
\hline \multirow{2}{*}{$\operatorname{lnCI}$} & & $-0.0890^{* *}$ \\
\hline & & $(-2.2739)$ \\
\hline \multirow{2}{*}{ Size } & $0.0154^{\star \star \star}$ & $0.0153^{\star * \star}$ \\
\hline & $(23.2437)$ & $(23.1371)$ \\
\hline \multirow{2}{*}{ Lev } & $-0.0924^{\star * \star}$ & $-0.0922^{\star * \star}$ \\
\hline & $(-22.5413)$ & $(-22.5041)$ \\
\hline \multirow{2}{*}{ Sgr } & $0.1694^{\star * *}$ & $0.1696^{* * *}$ \\
\hline & $(23.4669)$ & $(23.4856)$ \\
\hline \multirow{2}{*}{ Egr } & $0.0033^{\star * *}$ & $0.0033^{* * *}$ \\
\hline & $(22.3854)$ & $(22.3641)$ \\
\hline \multirow{2}{*}{ Q } & $0.0074^{\star * *}$ & $0.0073^{* * *}$ \\
\hline & $(18.2310)$ & $(18.1735)$ \\
\hline \multirow{2}{*}{ Owner } & $-0.0123^{\star * *}$ & $-0.0123^{* * *}$ \\
\hline & $(-7.6549)$ & $(-7.6740)$ \\
\hline \multirow{2}{*}{ Intercept } & $-0.0100^{* * *}$ & $-0.0100^{* * *}$ \\
\hline & $(-7.6523)$ & $-7.6336)$ \\
\hline Year dummy variables & Yes & Yes \\
\hline Adj $R^{2}$ & 0.4903 & 0.4898 \\
\hline $\mathrm{N}$ & 3.630 & 3.630 \\
\hline
\end{tabular}

Notes: ${ }^{* *}$ Significant at $1 \% .{ }^{* *}$ Significant at $5 \% .{ }^{*}$ Significant at $10 \%$.

Numbers in brackets represent the significance test statistics (t-value). 
In addition, the regression results of control variables in Model (1) are as follows: (1) Size is positively associated with $\mathrm{ROA}$ at the $1 \%$ significance level $(\beta=-0.0154, p<0.01)$. This is because a company with greater sales usually has larger market share and is more competitive, which promotes the improvement of corporate performance. (2) Lev has a negative correlation with ROA at the $1 \%$ significance level $(\beta=-0.0924, p<0.01)$. This is mainly because a high level of debt holding exposes a firm to higher operating risks and greater debt repayment pressure, which in turn restricts the firm's financial decisions and thus inhibits performance improvements. (3) Sgr is positively associated with ROA at the $1 \%$ significance level $(\beta=0.1694, p<0.01)$. The reason for this is that a company with a high sustainable growth rate based on the financial indicators of the previous year may perform better this year due to its existing efficient operations. (4) Egr and ROA are positively correlated at the $1 \%$ significance level $(\beta=0.0033, p<0.01)$, indicating that the faster a company's profitability improves, the better its performance will be. (5) Q has a positive effect on ROA at the $1 \%$ significance level $(\beta=0.0074, p<0.01)$. Tobin's $\mathrm{Q}$ ratio reflects investor expectations of a company's prospects. The higher the expectation, the more opportunities the company may have to improve corporate performance. (6) Owner has a negative association with ROA at the $1 \%$ significance level $(\beta=-0.0123, p<0.01)$, suggesting that the performance of a state-owned company is substantially worse than that of a non-state-owned company in Chinese manufacturing industry, which is closely related to the typical challenges in stateowned firms such as personnel redundancy and the agency problem.

Model (2) tests the influence of $\operatorname{lnCI}$ on ROA. The results reveal a negative association between $\operatorname{lnCI}$ and $\mathrm{ROA}$ at the $5 \%$ significance level $(\beta=-0.0890, p<0.05)$, thus providing support for Hypothesis $2 \mathrm{~b}$. Hence, we conclude that, although structural holes provide firms with information and control benefits, they also deprive firms of opportunities to gain external collective governance, which in turn puts them at greater risk. The regression results of control variables in Model (2) are similar to that of model (1): Lev and Owner are negatively correlated with ROA at the $1 \%$ significance level, and Sgr, Egr and Q are positively associated with $\mathrm{ROA}$ at the $1 \%$ significance level.

Furthermore, a Durbin-Wu-Hausman post-estimation test is performed to test the endogeneity of supply network position. Referencing the approach of Bellamy, Ghosh, and Hora (2014), closeness centrality (lnCloseness) is selected as the instrument which has no significant correlation with corporate performance but is significantly correlated with lnDegree and $\operatorname{lnCI}$. Firstly, lnDegree and $\operatorname{lnCI}$ were regressed on all assumed exogenous variables separately, and the predicted error terms for them were calculated. The regression results are presented in Table 3 (Model (1) and Model (2)): lnCloseness is positively associated with both $\ln$ Degree $(\beta=0.0256)$ and $\operatorname{lnCI}(\beta=0.0026)$ at the $1 \%$ significance level and the significance test statistics of lnCloseness in the two models yield F-values of 31.03 and 16.82, respectively, both of which are higher than 10 . These results suggest that lnCloseness is not a weak instrument.

Secondly, the predicted error terms from the previous stage are added to the original count model to conduct endogeneity test. According to the results, the endogeneity test statistics of lnDegree has p-value of $0.1141(>0.1)$, indicating that we fail to reject the null that degree centrality is exogenous. In other words, the parameter estimates for lnDegree in 
the original count model do not appear to be unduly influenced by endogeneity. However, the endogeneity test associated with structural holes abundance is significant, which has pvalue of $0.06(<0.1)$.

To solve the endogeneity problem between $\operatorname{lnCI}$ and ROA, a two-stage least squares (2SLS) estimation procedure was adopted. In the first stage, $\operatorname{lnCI}$ was regressed on all assumed exogenous variables (Model $(2)$ in Table 3 ), and the predicted values for it $(\widehat{\operatorname{lnCI}})$ were calculated. Subsequently, we conducted the second-stage regression with the predicted values from the first stage to replace $\operatorname{lnCI}$ in the original count model. The results are presented in model (3) of Table 3: $\widehat{\ln C I}$ is negatively correlated with ROA at the $5 \%$ significance level $(\beta=-0.5626, p<0.05)$, supporting the previous conclusion.

Table 3. Results of endogeneity test

\begin{tabular}{|c|c|c|c|}
\hline Variables & (1) $\operatorname{lnDegree}$ & (2) $\ln \mathrm{CI}$ & (3) ROA \\
\hline lnCloseness & $\begin{array}{l}0.0256^{* * *} \\
(13.2054)\end{array}$ & $\begin{array}{c}0.0026^{* * *} \\
(9.2151)\end{array}$ & \\
\hline $\ln C I$ & & & $\begin{array}{l}-0.5626^{\star *} \\
(-2.1762)\end{array}$ \\
\hline Size & $\begin{array}{c}0.0105^{\star * *} \\
(5.5674)\end{array}$ & $\begin{array}{l}0.0007^{\star *} \\
(2.3600)\end{array}$ & $\begin{array}{l}0.0157^{* * *} \\
(22.3356)\end{array}$ \\
\hline Lev & $\begin{array}{l}-0.0259^{* *} \\
(-2.2271)\end{array}$ & $\begin{array}{l}-0.0030^{*} \\
(-1.7354)\end{array}$ & $\begin{array}{l}-0.0933^{* * x} \\
(-22.5421)\end{array}$ \\
\hline Sgr & $\begin{array}{l}-0.0385^{\star} \\
(-1.8804)\end{array}$ & $\begin{array}{l}-0.0053^{\star} \\
(-1.7558)\end{array}$ & $\begin{array}{l}0.1669^{* * *} \\
(22.6569)\end{array}$ \\
\hline Egr & $\begin{array}{c}0.0003 \\
(0.8116)\end{array}$ & $\begin{array}{c}0.0000 \\
(0.7145)\end{array}$ & $\begin{array}{l}0.0033^{* * *} \\
(22.4378)\end{array}$ \\
\hline Q & $\begin{array}{c}-0.0005 \\
(-0.4628)\end{array}$ & $\begin{array}{l}-0.0003^{*} \\
(-1.6516)\end{array}$ & $\begin{array}{l}0.0072^{* * *} \\
(17.6268)\end{array}$ \\
\hline Owner & $\begin{array}{c}-0.0069 \\
(-1.5185) \\
\end{array}$ & $\begin{array}{l}-0.0016^{\star *} \\
(-2.3767)\end{array}$ & $\begin{array}{c}-0.0130^{* * *} \\
(-7.8926)\end{array}$ \\
\hline Intercept & $\begin{array}{c}0.0211^{\star * *} \\
(5.6305)\end{array}$ & $\begin{array}{c}0.0035^{\star * *} \\
(6.2762)\end{array}$ & $\begin{array}{c}-0.0087^{* * *} \\
(-5.8266)\end{array}$ \\
\hline Year dummy variables & Yes & Yes & Yes \\
\hline Adj $R^{2}$ & 0.0693 & 0.0378 & 0.4898 \\
\hline $\mathrm{N}$ & 3.630 & 3.630 & 3.630 \\
\hline
\end{tabular}

Notes: Models (1) and (2) depict the results for the first-stage regression of Durbin-Wu-Hausman post-estimation test/2SLS considering potentially endogenous variables network centrality and structural holes abundance, respectively. Models (3) are the corresponding results for the second-stage regression of 2SLS considering structural holes abundance. ${ }^{* *}$ Significant at $1 \%$. ** Significant at 5\%. * Significant at $10 \%$. Numbers in brackets represent the significance test statistics (t-value).

\subsection{Robustness results}

To test the reliability of this conclusion, this paper also tests the robustness of the research results by altering the measures of firm performance and network position characteristics. For firm performance, return on equity (ROE) is used to replace ROA for regression analy- 
sis. The results are presented in Table 4 (Model (1) and Model (2)): lnDegree is negatively associated with ROE at the $1 \%$ significance level $(\beta=-0.0348, p<0.01)$, and $\operatorname{lnCI}$ has a negative effect on ROE at the $5 \%$ significance level $(\beta=-0.2031, p<0.05)$.

In terms of network position characteristics, eigenvector (Eigenvector) and betweenness centrality (lnBetweenness) are used as alternative indicators for lnDegree and $\operatorname{lnCI}$, respectively. The results are presented in Table 4 (Model (3) and Model (4)): both Eigenvector $(\beta=-0.1025, p<0.05)$ and $\ln$ Betweenness $(\beta=-0.0006, p<0.05)$ are negatively associated with ROA at the $5 \%$ significance level. Thus, the results of robustness testing support the previous conclusion.

Table 4. Robustness test results

\begin{tabular}{|c|c|c|c|c|}
\hline Variables & (1) ROE & (2) ROE & (3) $\mathrm{ROA}$ & (4) $\mathrm{ROA}$ \\
\hline $\ln$ Degree & $\begin{array}{c}-0.0348^{\star * *} \\
(-2.6214)\end{array}$ & & & \\
\hline $\ln C I$ & & $\begin{array}{l}-0.2031^{\star *} \\
(-2.2405)\end{array}$ & & \\
\hline Eigenvector & & & $\begin{array}{l}-0.1025^{* *} \\
(-2.2692)\end{array}$ & \\
\hline lnBetweenness & & & & $\begin{array}{c}-0.0006^{\star *} \\
(-2.0807)\end{array}$ \\
\hline Size & $\begin{array}{l}0.0309^{* * *} \\
(20.1014)\end{array}$ & $\begin{array}{l}0.0306^{* * *} \\
(20.0220)\end{array}$ & $\begin{array}{l}0.0153^{* * *} \\
(23.1255)\end{array}$ & $\begin{array}{l}0.0154^{* * *} \\
(23.1106)\end{array}$ \\
\hline Lev & $\begin{array}{l}-0.1349^{\star * *} \\
(-14.2150)\end{array}$ & $\begin{array}{l}-0.1348^{* * *} \\
(-14.1924)\end{array}$ & $\begin{array}{l}-0.0920^{* * *} \\
(-22.4412)\end{array}$ & $\begin{array}{l}-0.0917^{\star * *} \\
(-22.3516)\end{array}$ \\
\hline Sgr & $\begin{array}{l}0.3076^{\star * *} \\
(18.3904)\end{array}$ & $\begin{array}{l}0.3079^{* * *} \\
(18.4054)\end{array}$ & $\begin{array}{l}0.1699^{* * *} \\
(23.5260)\end{array}$ & $\begin{array}{l}0.1698^{* * *} \\
(23.5111)\end{array}$ \\
\hline Egr & $\begin{array}{l}0.0091^{* * *} \\
(26.9017)\end{array}$ & $\begin{array}{l}0.0091^{\star * *} \\
(26.8883)\end{array}$ & $\begin{array}{l}0.0033^{* * *} \\
(22.2829)\end{array}$ & $\begin{array}{l}0.0033^{* * *} \\
(22.3217)\end{array}$ \\
\hline Q & $\begin{array}{l}0.0098^{\star * *} \\
(10.4770)\end{array}$ & $\begin{array}{l}0.0098^{\star * *} \\
(10.4273)\end{array}$ & $\begin{array}{l}0.0074^{\star * *} \\
(18.2678)\end{array}$ & $\begin{array}{l}0.0074^{* * *} \\
(18.2604)\end{array}$ \\
\hline Owner & $\begin{array}{c}-0.0245^{\star * *} \\
(-6.5959)\end{array}$ & $\begin{array}{c}-0.0247^{\star * *} \\
(-6.6221)\end{array}$ & $\begin{array}{c}-0.0121^{* * *} \\
(-7.5112)\end{array}$ & $\begin{array}{c}-0.0121^{\star * *} \\
(-7.5142)\end{array}$ \\
\hline Intercept & $\begin{array}{c}-0.0136^{* * *} \\
(-4.4862)\end{array}$ & $\begin{array}{c}-0.0136^{* * *} \\
(-4.4566)\end{array}$ & $\begin{array}{c}-0.0103^{* * *} \\
(-7.8603)\end{array}$ & $\begin{array}{c}-0.0106^{* * *} \\
(-8.0398)\end{array}$ \\
\hline Year dummy variables & Yes & Yes & Yes & Yes \\
\hline Adj $R^{2}$ & 0.4012 & 0.4009 & 0.4898 & 0.4897 \\
\hline $\mathrm{N}$ & 3.630 & 3.630 & 3.630 & 3.630 \\
\hline
\end{tabular}

Notes: ${ }^{* *}$ Significant at $1 \% .{ }^{*}$ Significant at $5 \% .{ }^{*}$ Significant at $10 \%$. Numbers in brackets represent the significance test statistics (t-value).

\section{Conclusions}

As companies strengthen contacts with their customers and suppliers, it becomes especially important to assess whether these close relationships have contributed to the firm's operational efficiency and performance. This paper measures the network position characteristics 
of each firm using the indicators of network centrality and structure holes and investigates their effects on corporate performance. This empirical study draws the following two main conclusions. First, degree centrality is significantly negatively correlated with corporate performance, suggesting that a firm with higher supply network centrality is more likely to perform relatively poorly. The result supports the proposition that companies at the center of supply networks are more vulnerable to adverse effects from their partners' deteriorating business conditions, which can greatly influence corporate performance by lowering the firms' profitability and hindering their development. Second, structural holes abundance has a significant negative association with corporate performance. The result supports the proposition that a company with more structural holes in a supply network is more likely to perform poorly due to the loss of external collective governance mechanisms which can prevent opportunism of firm's partners or the loss of favorable opportunities to cooperate with others.

These results have key implications for manufacturing companies and governments. First, the competitive environment companies face today includes not only competition from individual firms, but also from the network environments. Thus, companies embedded in a same network should jointly maintain the health and harmony of the network environment and actively respond to network risks. Specifically, Firms in a supply network should foster mutual trust and work together to preserve regular trading order and prevent supply chain risk. Second, the empirical results demonstrate that the performance of companies located in the center of a supply network is relatively low. This is mainly due to the negative knock-on effects among members. Therefore, a company should enhance its own competitiveness to weaken the adverse effects from its dependence on others. Meanwhile, governments should formulate policies to improve the relevant market system to enhance firms' ability to manage risk. Third, according to the results of this paper, the advantages of structural holes in supply network cannot be effectively utilized in Chinese manufacturing industry. Hence, countries, especially developing countries, should speed up the process of marketization of their economies, and promote the free flow of information and resources between firms. What's more? The governments should complete market-related laws and regulations as soon as possible and create orderly trading environments to regulate corporate behavior and prevent vicious competition among companies.

Nevertheless, the present study suffers from some limitations. First, because of the difficulty of obtaining network data, some deviations may exist in the construction of the supply network. In particular, most network members in this study are non-listed company; that is, the companies have not publicly disclosed information on their main suppliers and customers, resulting in neglected links between some network members. In future research, because of the expected increase in publicly disclosed information on unlisted companies, a more reasonable and complete supply network can be constructed. Second, in the construction of the supply network, this study considers only the existence of links between the company and its five biggest suppliers and customers, whereas it does not consider the intensity of these links. In fact, links between network nodes have different strength, which reflects the importance of the two companies that are connected to each other. In particular, in a supply network, the relative size of the purchase and sales between suppliers and customers can 
reflect the strength of their relationship. Future investigation is thus warranted to consider the strength of network nodes when constructing supply networks.

\section{Funding}

This work was supported by the Key Program of National Social Science Foundation of China under Grant [No. 18ZDA095]; The National Social Science Foundation of China under Grant [17BGL234], and the Fundamental Research Funds for the Central Universities under Grant [DUT19RW208].

\section{Disclosure statement}

The authors have no competing financial, professional, or personal interests from other parties.

\section{References}

Ahern, K. R., \& Harford, J. (2014). The importance of industry links in merger waves. The Journal of Finance, 69(2), 527-576. https://doi.org/10.1111/jofi.12122

Akdogan, Y. E., \& Boyacioglu, M. A. (2014). The effect of corporate governance on firm performance: a case of Turkey. International Journal of Critical Accounting, 6(2), 187-210. https://doi.org/10.1504/IJCA.2014.063365

Anderson, E., \& Jap, S. D. (2005). The dark side of close relationships. MIT Sloan Management Review, 46(3), 75. Retrieved from http://sloanreview.mit.edu/

Autry, C. \& Griffis, S. (2008). Supply chain capital: The impact of structural and relational linkages on firm execution and innovation. Journal of Business Logistics, 29(1), 157-173. https://doi.org/10.1002/j.2158-1592.2008.tb00073.x

Bagul, A., \& Mukherjee, I. (2018). An insight into centralised sourcing strategy for enhancing performance and sustainability of multi-tier supply network. International Journal of Intelligent Enterprise, 5(1-2), 18-49. https://doi.org/10.1504/IJIE.2018.091183

Basole, R., \& Bellamy, M. (2014). Visual analysis of supply network risks: Insights from the electronics industry. Decision Support Systems, 67, 109-120. https://doi.org/10.1016/j.dss.2014.08.008

Baum, J. A., Calabrese, T., \& Silverman, B. S. (2015). Don't go it alone: Alliance network composition and startups' performance in Canadian biotechnology. Strategic Management Journal, 21(3), 267294. https://doi.org/10.1002/(SICI)1097-0266(200003)21:3<267::AID-SMJ89>3.0.CO;2-8

Bell, G. G. (2005). Clusters, networks, and firm innovativeness. Strategic Management Journal, 26, 287295. https://doi.org/10.1002/smj.448

Bellamy, M. A., Ghosh, S., \& Hora, M. (2014). The influence of supply network structure on firm innovation. Journal of Operations Management, 32(6), 357-373. https://doi.org/10.1016/j.jom.2014.06.004

Booth, L., Aivazian, V., Demirguc-Kunt, A., \& Maksimovic, V. (2001). Capital structures in developing countries. The Journal of Finance, 56(1), 87-130. https://doi.org/10.1111/0022-1082.00320

Borgatti, S., Mehra, A., \& Labianca, G. J. (2009). Network analysis in the social sciences. Science, 323(5916), 892-895. https://doi.org/10.1126/science.1165821

Burt, R. S. (1992). Structural holes: The social structure of competition. Harvard university press. 
Carnovale, S., Rogers, D. S., \& Yeniyurt, S. (2019). Broadening the perspective of supply chain finance: The performance impacts of network power and cohesion. Journal of Purchasing and Supply Management, 25(2), 134-145. https://doi.org/10.1016/j.pursup.2018.07.007

Chen, Y., Wang, Y., \& Lin, L. (2014). Independent directors' board networks and controlling shareholders' tunneling behavior. China Journal of Accounting Research, 7(2), 101-118. https://doi.org/10.1016/j.cjar.2013.09.002

Choi, T. Y., \& Krause, D. R. (2006). The supply base and its complexity: Implications for transaction costs, risks, responsiveness, and innovation. Journal of Operations Management, 24(5), 637-652. https://doi.org/10.1016/j.jom.2005.07.002

Choi, T. Y., \& Hong, Y. (2002). Unveiling the structure of supply networks: case studies in Honda, Acura, and DaimlerChrysler. Journal of Operations Management, 20(5), 469-493. https://doi.org/10.1016/S0272-6963(02)00025-6

Chuluun, T., Prevost, A., \& Puthenpurackal, J. (2014). Board ties and the cost of corporate debt. Financial Management, 43(3), 533-568. https://doi.org/10.1111/fima.12047

Coleman, J. S. (1988). Social capital in the creation of human capital. American Journal of Sociology, 94, S95-S120. https://doi.org/10.1086/228943

De Prato, G., \& Nepelski, D. (2014). Global technological collaboration network: network analysis of international co-inventions. The Journal of Technology Transfer, 39(3), 358-375. https://doi.org/10.1007/s10961-012-9285-4

Detthamrong, U., Chancharat, N., \& Vithessonthi, C. (2017). Corporate governance, capital structure and firm performance: evidence from Thailand. Research in International Business and Finance, 42, 689-709. https://doi.org/10.1016/j.ribaf.2017.07.011

Dhaliwal, D., Judd, J. S., Serfling, M., \& Shaikh, S. (2016). Customer concentration risk and the cost of equity capital. Journal of Accounting and Economics, 61(1), 23-48.

https://doi.org/10.1016/j.jacceco.2015.03.005

Dong, M. C., Liu, Z., Yu, Y., \& Zheng, J. H. (2015). Opportunism in distribution networks: The role of network embeddedness and dependence. Production and Operations Management, 24(10), 16571670. https://doi.org/10.1111/poms.12247

El-Khatib, R., Fogel, K., \& Jandik, T. (2015). CEO network centrality and merger performance. Journal of Financial Economics, 116(2), 349-382. https://doi.org/10.1016/j.jfineco.2015.01.001

Engelberg, J., Gao, P., \& Parsons, C. A. (2012). Friends with money. Journal of Financial Economics, 103(1), 169-188. https://doi.org/10.1016/j.jfineco.2011.08.003

Faruq, H. A., \& Weidner, M. L. (2018). Culture, institutions, and firm performance. Eastern Economic Journal, 1-16. https://doi.org/10.1057/s41302-016-0087-5

Granovetter, M. (1985). Economic action and social structure: the problem of embeddedness. American Journal of Sociology, 91(3), 481-510. https://doi.org/10.1086/228311

Gulati, R. (1998). Alliances and networks. Strategic Management Journal, 19(4), 293-317. https://doi.org/10.1002/(SICI)1097-0266(199804)19:4<293::AID-SMJ982>3.0.CO;2-M

Hochberg, Y. V., Ljungqvist, A., \& Lu, Y. (2007). Whom you know matters: Venture capital networks and investment performance. The Journal of Finance, 62(1), 251-301. https://doi.org/10.1111/j.1540-6261.2007.01207.x

Hoskisson, R. E., Hitt, M. A., \& Hill, C. W. (1993). Managerial incentives and investment in R\&D in large multiproduct firms. Organization Science, 4(2), 325-341. https://doi.org/10.1287/orsc.4.2.325

Irvine, P. J., Park, S. S., \& Ylldızhan, Ç. (2015). Customer-base concentration, profitability, and the relationship life cycle. The Accounting Review, 91(3), 883-906. https://doi.org/10.2308/accr-51246

Kao, T. W. D., Simpson, N. C., Shao, B. B., \& Lin, W. T. (2017). Relating supply network structure to productive efficiency: A multi-stage empirical investigation. European Journal of Operational Research, 259(2), 469-485. https://doi.org/10.1016/j.ejor.2016.11.008 
Kao, T. W. D., Su, H. C., \& Chen, Y. S. (2019). The curvilinear relationships between structural embeddedness and productive efficiency: An exploratory study. International Journal of Production Economics, 212, 176-185. https://doi.org/10.1016/j.ijpe.2019.02.020

Kim, Y., Choi, T. Y., Yan, T., \& Dooley, K. (2011). Structural investigation of supply networks: A social network analysis approach. Journal of Operations Management, 29(3), 194-211.

https://doi.org/10.1016/j.jom.2010.11.001

Kim, Y., Chen, Y. S., \& Linderman, K. (2015). Supply network disruption and resilience: A network structural perspective. Journal of operations Management, 33, 43-59. https://doi.org/10.1016/j.jom.2014.10.006

Kim, Y. H. (2017). The effects of major customer networks on supplier profitability. Journal of Supply Chain Management, 53(1), 26-40. https://doi.org/10.1111/jscm.12118

Lanier Jr, D., Wempe, W. F., \& Zacharia, Z. G. (2010). Concentrated supply chain membership and financial performance: Chain-and firm-level perspectives. Journal of Operations Management, 28(1), 1-16. https://doi.org/10.1016/j.jom.2009.06.002

Larcker, D. F., So, E. C., \& Wang, C. C. (2013). Boardroom centrality and firm performance. Journal of Accounting and Economics, 55(2-3), 225-250. https://doi.org/10.1016/j.jacceco.2013.01.006

Marsden, P. V. (2002). Egocentric and sociocentric measures of network centrality. Social Networks, 24(4), 407-422. https://doi.org/10.1016/S0378-8733(02)00016-3

Nee, V., Liu, L., \& DellaPosta, D. (2017). The entrepreneur's network and firm performance. Sociological Science, 4, 552-579. https://doi.org/10.15195/v4.a23

Park, S. H., Li, S., \& David, K. T. (2006). Market liberalization and firm performance during China’s economic transition. Journal of International Business Studies, 37(1), 127-147. https://doi.org/10.1057/palgrave.jibs. 8400178

Patatoukas, P. N. (2011). Customer-base concentration: Implications for firm performance and capital markets: 2011 American accounting association competitive manuscript award winner. The Accounting Review, 87(2), 363-392. https://doi.org/10.2308/accr-10198

Porter, M. E. (1980). Competitive strategy: Techniques for analyzing industries and competitors. The Free Press.

Rezapour, S., Srinivasan, R., Tew, J., Allen, J. K., \& Mistree, F. (2018). Correlation between strategic and operational risk mitigation strategies in supply networks. International Journal of Production Economics, 201, 225-248. https://doi.org/10.1016/j.ijpe.2018.04.014

Rothaermel, F. T. (2001). Incumbent's advantage through exploiting complementary assets via interfirm cooperation. Strategic Management Journal, 22(6-7), 687-699. https://doi.org/10.1002/smj.180

Sharma, A., Kumar, V., Yan, J., Borah, S. B., \& Adhikary, A. (2019). Understanding the structural characteristics of a firm's whole buyer-supplier network and its impact on international business performance. Journal of International Business Studies, 1-28. https://doi.org/10.1057/s41267-019-00215-X

Sun, Q., \& Tong, W. H. (2003). China share issue privatization: the extent of its success. Journal of Financial Economics, 70(2), 183-222. https://doi.org/10.1016/S0304-405X(03)00145-4

Uzzi, B. (1997). Social structure and competition in interfirm networks: The paradox of embeddedness. Administrative Science Quarterly, 35-67. https://doi.org/10.2307/2393808

Vissa, B., \& Chacar, A. S. (2009). Leveraging ties: the contingent value of entrepreneurial teams' external advice networks on Indian software venture performance. Strategic Management Journal, 30(11), 1179-1191. https://doi.org/10.1002/smj.785

Weisbuch, G., \& Battiston, S. (2007). From production networks to geographical economics. Journal of Economic Behavior \& Organization, 64(3-4), 448-469. https://doi.org/10.1016/j.jebo.2006.06.018

Withers, M. C., \& Fitza, M. A. (2017). Do board chairs matter? The influence of board chairs on firm performance. Strategic Management Journal, 38(6), 1343-1355. https://doi.org/10.1002/smj.2587 
Whittington, K. B., OwenSmith, J., \& Powell, W. W. (2009). Networks, propinquity, and innovation in knowledge-intensive industries. Administrative Science Quarterly, 54(1), 90-122. https://doi.org/10.2189/asqu.2009.54.1.90

Xiao, Z., \& Tsui, A. S. (2007). When brokers may not work: The cultural contingency of social capital in Chinese high-tech firms. Administrative Science Quarterly, 52(1), 1-31. https://doi.org/10.2189/asqu.52.1.1

Yan, T., Choi, T. Y., Kim, Y., \& Yang, Y. (2015). A theory of the nexus supplier: A critical supplier from a network perspective. Journal of Supply Chain Management, 51(1), 52-66. https://doi.org/10.1111/jscm.12070

Yang, H., Lin, Z., \& Lin, Y. (2010). A multilevel framework of firm boundaries: firm characteristics, dyadic differences, and network attributes. Strategic Management Journal, 31(3), 237-261. https://doi.org/10.1002/smj.815

Zaheer, A., \& Bell, G. G. (2005). Benefiting from network position: firm capabilities, structural holes, and performance. Strategic Management Journal, 26(9), 809-825. https://doi.org/10.1002/smj.482 